\title{
Effect of glycerol-induced acute renal failure and di-2-ethylhexyl phthalate on the enzymes involved in biotransformation of xenobiotixs
}

\author{
Etelka Kertai ${ }^{1}$, G. Hollósi², Judit Kovács ${ }^{3}$, V. Varga ${ }^{2,4}$ \\ ${ }^{1}$ Department of Pharmaceutical Technology, \\ ${ }^{2}$ Department of Animal Anatomy and Physiology, \\ ${ }^{3}$ Institute of Pathology University of Debrecen, Debrecen, Hungary \\ ${ }^{4}$ Brain Research Center, University of Tampere Medical School, Tampere, Finland
}

Received: October 9, 2000

Accepted: January 4, 2001

The effects of di-(2-ethylhexyl)-phthalate (DEPH) on the levels of cytochrome P-450 and b5 monooxygenases were studied in the rat kidney and liver in acute renal failure induced by glycerol. Intramuscular injection of glycerol $\left(50 \%, 10 \mathrm{ml} / \mathrm{kg}^{-1}\right)$ to rats produced proximal tubular damage and acute renal failure. The indicators of renal function, serum urea and creatinine significantly increased (480 and 350 percent, respectively). In control and glycerol-treated animals DEPH had no significant effect on the concentrations of serum urea and creatinine. Twenty-four hours after glycerol injection the total amount of cytochrome P-450 and $b_{5}$ significantly decreased in renal but increased in liver microsomal fractions. Moreover, 48 and 72 hours after glycerol injection the level of cytochrome P-450 and $\mathrm{b}_{5}$ significantly increased in both organs. A single dose of DEPH ( $2 \mathrm{ml} \cdot \mathrm{kg}^{-1}$, i.p. $)$ also elevated the total cytochrome P-450 and $\mathrm{b}_{5}$ in control animals. This enhancing effect of DEPH was additive to that of glycerol in glycerolinduced acute renal failure.

These results indicate that DEPH and glycerol evoked pathological changes may affect the metabolism of xenobiotics plus endogenous hormones in the liver and in kidney.

Keywords: glycerol induced acute renal failure, rhabdomyolysis, myoglobinuria di-2ethylhexyl phthalate, cytochrome P-450, cytochrome $b_{5}$, xenobiotics, acute renal failure, glycerol, proximal tubular damage, metabolism of xenobiotics

Correspondence should be addressed to

Ass. Prof. Gábor Hollósi

Debrecen University

Department of Animal Anatomy and Physiology

H-4010 Debrecen, P.O. Box 15, Hungary

Phone: 36-(52)-512-900 ext. 2739

E-mail: hollosig@delfin.klte.hu 
Medical devices such as transfusion sets, dialysis units, disposable syringes, vascular grafting materials, catheters and storage bags for blood, dialysis and infusion solutions are often made of plastic. These plastic materials are composed of polyvinyl chloride (PVC) and plasticizers such as di-(2-ethylhexyl)-phthalate (DEPH). In some plastic blood packs the amount of DEPH is $35-40 \%$ of the plastic materials [3]. Since DEPH is not covalently bound to PVC, it may be liberated into fluids and accumulate as xenobiotic in blood and organs of patients. Patients suffering from acute and chronic renal failure (ARF and $\mathrm{CRF}$ ) are often subjected to hemo- and peritoneal dialyses and receive intravenous infusions. For these patients DEPH is a potentially hazardous compound. In rodents, long-term administration of DEPH and dibutyryl phthalate causes renal cysts [39] and proliferation of peroxisomes in the liver and kidney. Phthalate esthers increase the liver mass and the concentration of cytochrome P-450 enzyme system [21].

The cytochrome P-450 (CYP superfamily) of mixed function oxidases (MFO) are the principal enzymes in the metabolism of xenobiotics. They play a role in the metabolism of fatty acids and steroids, biotransformation of toxins, oxidation of nitrogen, alcohol and aldehyde, oxidative deamination, reduction of aldehydes and ketones and hydrolysis and demethylation reactions. They are heme-containing enzymes that serve as the terminal oxidase component in the electron transport system of the endoplasmatic reticulum. In general, the second component of the system is a flavoprotein cytochrome P-450 reductase that transfers reducing equivalents from NADPH to cytochrome P-450. In addition, cytochrome $b_{5}$ and cytochrome $b_{5}$ reductase can also donate an electron from NADH to cytochrome P-450 [18]. The concentrations of these enzymes are highest in the liver [10]. In the kidney, the highest concentrations are found in the cortex and proximal tubular epithelium [8, 18, 42].

Recently, important insights into the pathophysiology of different types of ARF have emerged [41], but only a few studies were dealing with the metabolism of xenobiotics during renal failure [5, 31]. We investigated here the effects of ARF and DEHP on the total amounts of cytochrome P-450 and $b_{5}$ enzyme proteins in the rat kidneys and liver. Acute renal failure was produced by the intramuscular injection of glycerol as an experimental model of rhabdomyolysis and myoglubinuria [34, 35]. 


\section{Materials and Methods}

\section{Chemicals}

Di-2-ethylhexyl phthalate (>97\% pure) was purchased from Fluka AG (Buchs, Switzerland). All other reagents were obtained from Sigma (USA) or Boehringer Manheim (Germany).

\section{Experimental model of acute renal failure}

Adult, male albino rats of Wistar strain $(239 \pm 20 \mathrm{~g})$ were housed six per cage and divided into four experimental groups: controls (A), and glycerol-treated (B), DEHPtreated (C) and glycerol+DEHP-treated (D) rats. The rats were deprived of drinking water for $24 \mathrm{~h}$ but had free access to food. Acute renal failure was produced by intramuscular injection of glycerol as in [5]. An intramuscular injection of $50 \% \mathrm{v} / \mathrm{v}$ glycerol in sterile saline $(0.9 \% \mathrm{NaCl}$ solution $)$ was given at a dose of $10 \mathrm{ml} \cdot \mathrm{kg}^{-1}$. Control animals were injected with sterile saline $\left(10 \mathrm{ml} \cdot \mathrm{kg}^{-1}\right)$. Drinking water was immediately avaible for rats after the injections. Twenty-four hours after the injections of glycerol or saline, the rats in groups C and D were injected intraperitonally with a dose of $2 \mathrm{ml} \cdot \mathrm{kg}^{-1}$ DEHP. The injections were always given between 2 and 3 p.m.

\section{Biochemical investigations}

Serum creatinine and urea were measured by the standard spectrophotometric methods [12]. The microsomal fractions of kidney and liver were prepared by the method of Miles et al. [22]. Briefly, the kidney cortex and liver were homogenized $(0.25 \mathrm{~g}$ tissue $/ \mathrm{ml})$ in ice-cold buffer with a motor-driven all-glass Potter-Elvehjem homogenizer. Homogenising buffer A was composed of $0.05 \mathrm{M}$ Tris- $\mathrm{HCl}$, $0.154 \mathrm{M} \mathrm{KCl}, 0.2 \mathrm{mM}$ EDTA and $1.0 \mathrm{mM}$ dithiothreitol. The homogenate was first centrifuged for $20 \mathrm{~min}$ at $9,000 \mathrm{~g}$. The pellet was discarded and the supernatant recentrifuged at 105,000 $\mathrm{g}$ for $60 \mathrm{~min}$. The pellet was resuspended in buffer B (100 mM Tris- $\mathrm{HCl}, \mathrm{pH} 7.4,0.2 \mathrm{mM}$ EDTA and $1 \mathrm{mM}$ dithiothreitol) and the centrifugation was repeated at the same centrifugal force. The pellet was finally suspended in buffer B $(10 \mathrm{mg}$ protein/ml) and used as microsomal fraction. The whole procedure was done at $4{ }^{\circ} \mathrm{C}$. Protein content was measured by the method of Lowry et al. [19] using bovine serum albumin as standard. The amounts of total microsomal cytochrome P450 and cytochrome $b_{5}$ were estimated according to the method of Omura and Sato [27]. 


\section{Morphological studies}

Kidney and liver slices were fixed in phosphate-buffered $10 \%$ formalin. Five $\mu \mathrm{m}$ thick paraffin sections were cut and subsequently stained with hematoxylin and eosin and examined by a light microscope.

\section{Ultrastructural studies}

The kidney and liver samples were processed for electron microscopy using the method of Okuda et al. [25]. The specimens were fixed in 1.4\% glutaraldehyde buffered with $0.1 \mathrm{M}$ cacodylate, postfixed in ice-cold $1 \%$ osmium tetroxide in the same buffer for $2 \mathrm{~h}$, dehydrated in a graded series of ethanol and embedded in Epon 812. Ultrathin sections were stained with uranyl acetate and lead citrate and examined with JEOL 200 type of electron microscope.

\section{Statistical analysis}

The results are given as mean values, \pm S.D. Statistical analysis were done by the non-paired Student's-test [32]. The probability level (p) of $<0.05$ was considered statistically significant.

\section{Results}

The intramuscular injection of $50 \%$ glycerol produced an acute renal failure leading within $24 \mathrm{~h}$ to the uremic state. The concentrations of urea increased 4.3- and 4.8-fold and creatinine 3.2- and 3.5-fold after 24 and 48 h, respectively (Figs 1 and 2).

The glycerol injection alone caused massive tubular epithelial cell swelling, vacuolar degeneration, necrosis, desquamation of cells and cast formation. It was accompanied by glomerular dilatation (Fig. 3B) and increased diameters of capillaries (Fig. 3C). Electron microscopic examinations revealed characteristic alterations in the tubule cells. The mitochondria were enlarged in some parts with distended cristae. In addition, the destruction and lysis of the cristae resulting in a vacuolated pattern and inclusion bodies surrounded by membranes were also discernible within the mitochondria (Fig. 3D). Two and three days after the glycerol injection number of cells were dividing in proximal and distal tubules, indicating regeneration of kidney tissue. 


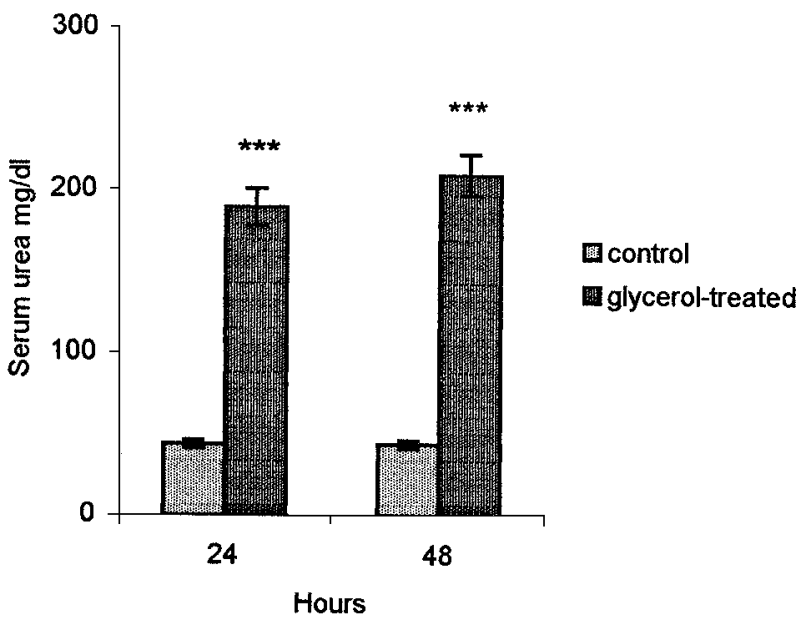

Fig. 1. Serum urea level in glycerol-treated rats. Mean values \pm S.D., $N=5, * * * p<0.001$, when comparing glycerol-treated and control rats

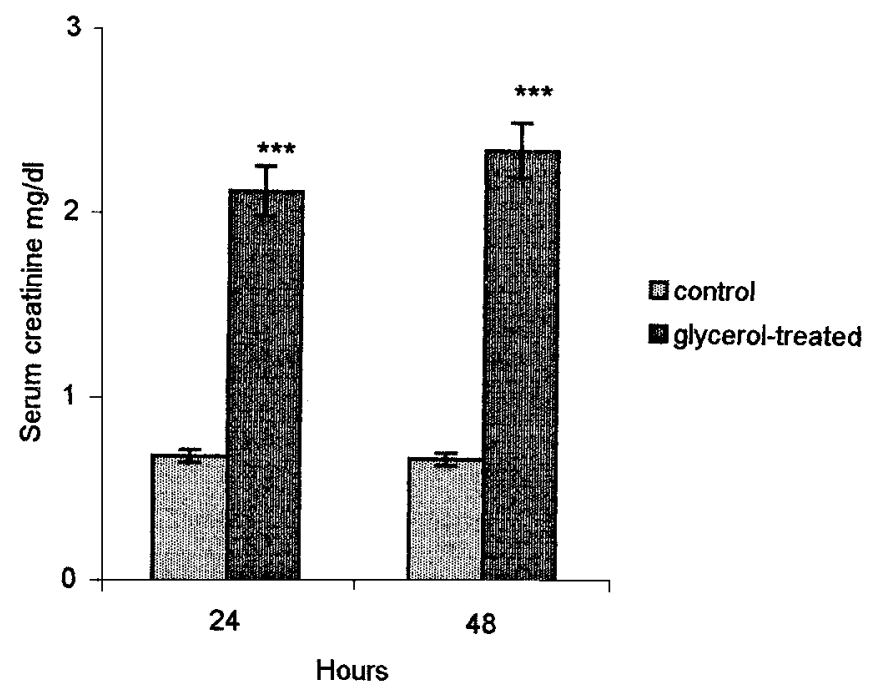

Fig. 2. Serum creatinine level in glycerol-treated rats. Mean values \pm S.D., $N=5, * * * p<0.001$, when comparing glycerol-treated and control rats 

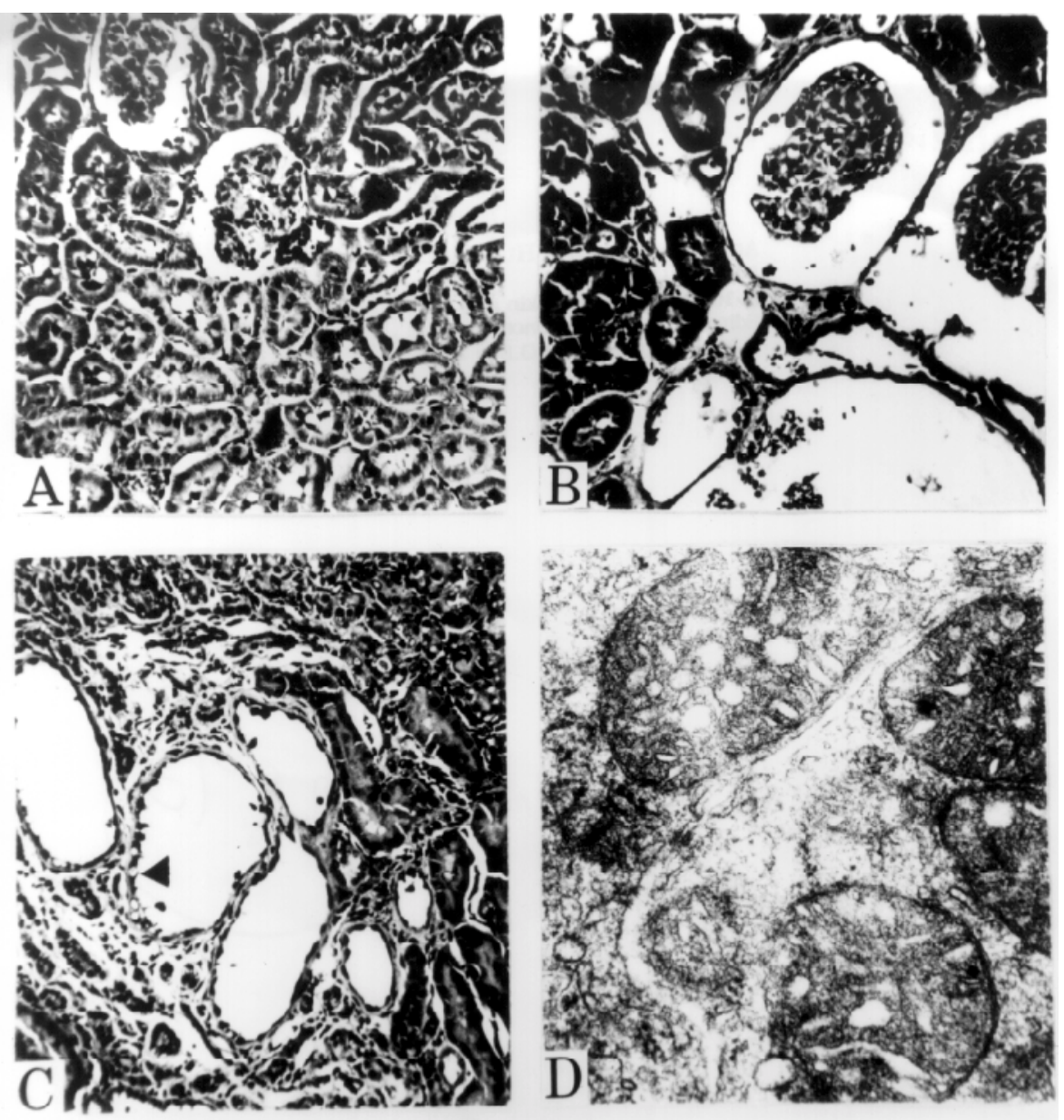

Fig. 3. Kidney sections from control and DEPH-treated rats in glycerol-induced acute renal failure. A-C. Light microscopic photomicrographs (magnification: $\times 200$ ). A-section of an intact kidney with the normal size of corpusculum renis and nephron. B-section of kidney from DEPH-treated rat suffering from acute renal impairment, a glomerular dilatation can be seen. C-section the same as B with vacuolization of tubular and capillar endothel cells. D-section, fine structure of mitochondria from glycerol and DEPH-treated animals. (magnification: $\times 30,000$ ). Enlarged mitochondria with slight distention, destruction and lysis of cristae

In all livers examined the wast majority of cells appeared normal. There was no evidence of serious hepatocellular damage in the rats with glycerol-induced ARF. No significant morphological changes were visible in the liver of the glycerol+DEPHtreated rats, but in some cells hydropic vacuolation was evident upon light microscopic examinations (not shown). 
Table I

Changes in the absolute and relative kidney mass of glycerol and DEHP-treated animals

\begin{tabular}{llccr}
\hline $\begin{array}{c}\text { Experimental } \\
\text { groups }\end{array}$ & $\begin{array}{c}\text { Kidney } \\
\text { weight }(\mathrm{g})\end{array}$ & $\begin{array}{c}\text { Increase } \\
(\%)\end{array}$ & $\begin{array}{c}\text { Relative kidney weight } \\
(\mathrm{g} / 100 \mathrm{~g} \text { body w. })\end{array}$ & $\begin{array}{c}\text { Increase } \\
(\%)\end{array}$ \\
\hline Controls & $1.36 \pm 0.15$ & & $0.54 \pm 0.10$ & - \\
Glycerol treated & $1.95 \pm 0.05^{* *}$ & 43.31 & $0.71 \pm 0.02 * *$ & 30.50 \\
DEHP treated & $1.50 \pm 0.11^{*}$ & 10.29 & $0.61 \pm 0.09 *$ & 13.32 \\
Glycerol+DEHP treated & $2.43 \pm 0.20^{* * *}$ & 80.33 & $0.89 \pm 0.02 * * *$ & 63.97 \\
\hline
\end{tabular}

$* \mathrm{P}<0.01, * * \mathrm{P}<0.05, * * * \mathrm{P}<0.001$

Results are the mean values $( \pm$ S.D) of five animals.

The kidney mass and relative mass of kidney significantly increased after glycerol and DEHP injections (Table I). DEPH caused further tissue swelling in the kidney and a number of vacuola was discernible in capillaries (see Fig. 3C and arrow) applied after glycerol DEHP increased the mass of kidney by 78 percent, indicating swelling of tissue.

In glycerol-induced renal insufficiency, the total amounts of cytochrome P-450 and $b_{5}$ significantly decreased in the kidney by $21 \pm 4$ and $18 \pm 3 \%$, but increased in the liver microsomal fraction by $15 \pm 3$ and $17 \pm 2 \%$, respectively, after 24 hours (Figs 4, 5, 6 and 7).

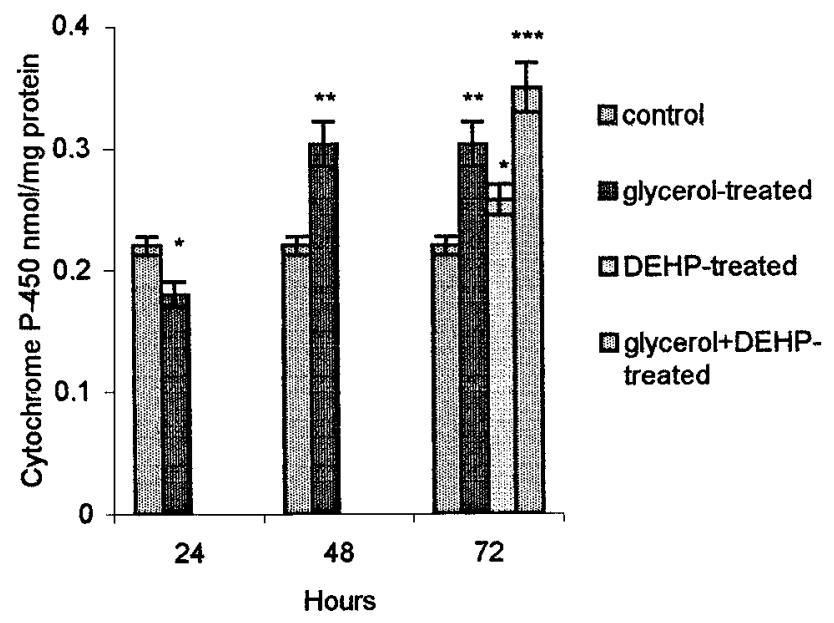

Fig. 4. Effect of glycerol and DEHP on the level of microsomal cytochrome P-450 in the kidney. Mean values \pm S.D., $\mathrm{N}=5$. $* \mathrm{p}<0.05, * *_{\mathrm{p}}<0.01$, $* * *_{\mathrm{p}}<0.001$, when comparing DEHP-, glycerol-, Glycerol and DEHP-treated and control rats 


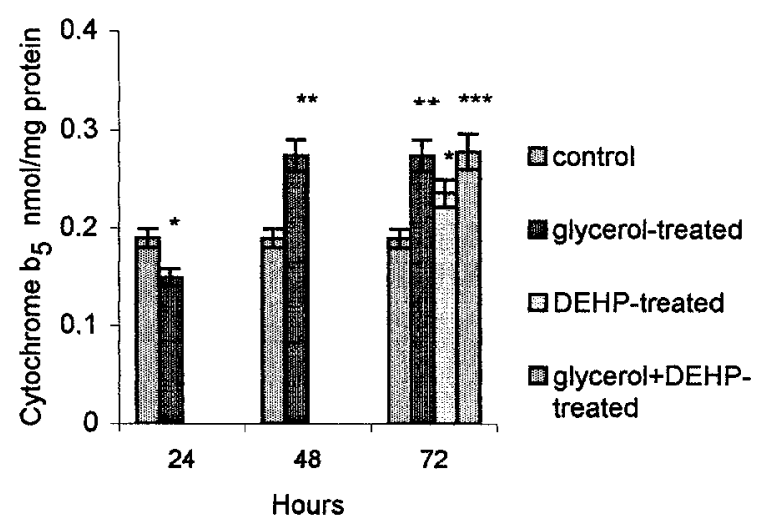

Fig. 5. Effect of glycerol and DEHP on the level of microsomal cytochrome b5 in the kidney. Mean values \pm S.D., $\quad \mathrm{N}=5, \quad * \mathrm{p}<0.05, \quad * * \mathrm{p}<0.01, \quad * * * \mathrm{p}<0.001$, when comparing DEHP-, glycerol-, Glycerol and DEHP-treated and control rats

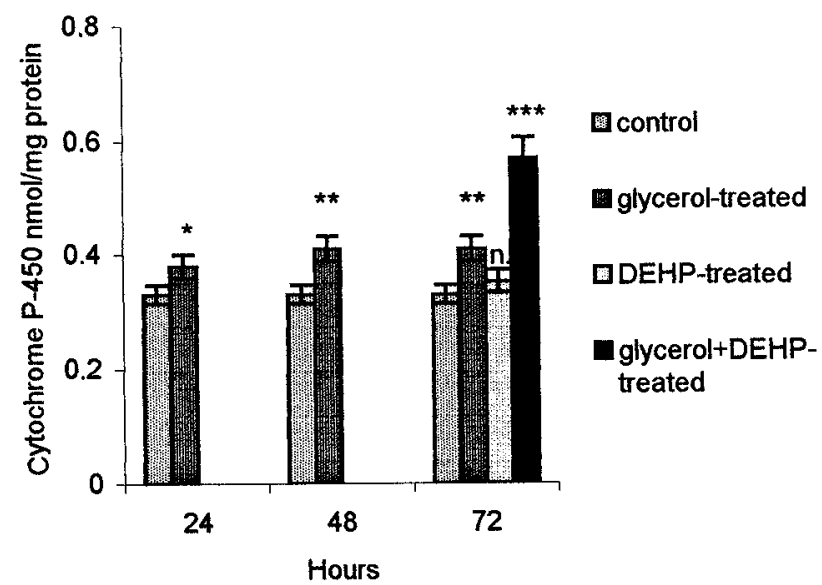

Fig. 6. Effect of glycerol and DEHP on the level of microsomal cytochrome P-450 in the liver. Mean values \pm S.D., $\quad \mathrm{N}=5, \quad * \mathrm{p}<0.05, \quad * * \mathrm{p}<0.01$, $* * * \mathrm{p}<0.001$, when comparing DEHP-, glycerol-, Glycerol and DEHP-treated and control rats

Two and three days after the glycerol treatment a significant increase in the concentration of enzymes was detected in the microsomal fractions of both organs. A single dose of DEHP also elevated the level of these enzymes, but the inductive effect of glycerol was greater than that of DEHP. This latter affect was additive to the effect of glycerol (Figs 4, 5, 6 and 7). 


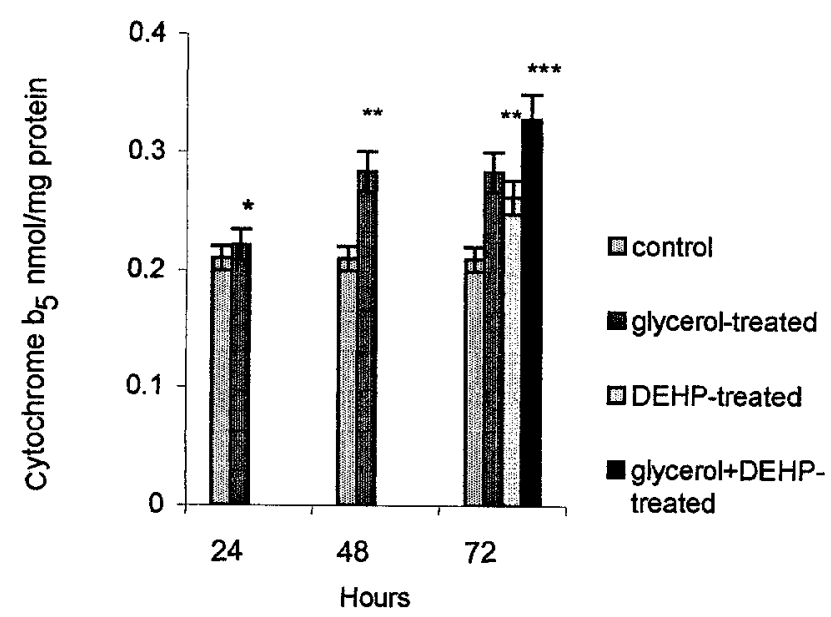

Fig. 7. Effect of glycerol and DEHP on the level of microsomal cytochrome $b_{5}$ in the liver. Mean values \pm S.D., $\mathrm{N}=5, * \mathrm{P}<0.05, * * \mathrm{P}<0.01, * * * \mathrm{P}<0.001$, when comparing DEHP-, glycerol-, Glycerol and DEHP-treated and control rats

\section{Discussion}

Crush syndromes, ischemia, metabolic disorders, inflammatory and intrinsic myopathies, excessive physical exercise, alcoholism, drugs, toxins, hypophosphatemia, hypokalemia often lead to degeneration of striated muscle. Rhabdomyolysis may result in myoglobinemia, myoglubinuria and finally in acute tubular and renal failure. Approximately $15 \%$ of acute renal failures are caused by myoglobin- and hemoglobinuria [41]. The most widely used animal model of acute renal failure is produced by intramuscular injection of hypertonic glycerol [14]. This intervention consistently produces severe acute tubular necrosis which is reminiscent in its clinical course of crush syndrome [34, 35]. In our experiments, morphological and functional changes were similar to those previously published $[4,35]$. The concentrations of urea and creatine increased by 3 to 5 times in serum, indicating a rapid decrease in renal function after glycerol injection (Figs 1 and 2). The morphological changes at $24 \mathrm{~h}$ point to epithelial cell degeneration, mainly in the proximal tubules. This may explain the significant decrease in the concentrations of cytochrome P-450 in the kidney microsomal fraction. On the second and third day, an increase in the amounts of cytochrome P-450 and $b_{5}$ enzymes were found in the kidney and liver. The former finding can be explained by regeneration of the epithelial cell layer in the proximal tubules. These findings differ from those encounterd in chronic renal failure [15]. 
The surgically evoked renal insufficiency does not affect the levels of cytochrome $\mathrm{P}-450$ and $\mathrm{b}_{5}$ in the remnant kidney [15].

The mechanism by which glycerol causes enzyme induction is likely to be multifactorial, similarly to the pathogenesis of glycerol-induced ARF [34]. Glycerol causes muscle injury, myolysis, hemolysis and exposes the kidney and liver to a large burden of heme proteins, myoglobin and hemoglobin. In addition, it diminishes blood volume, which is associated with renal vasoconstriction. Hypovolemia (dehydration) and vasoconstriction are the critical factors which predispose to myoglobinuric acute renal failure. The decrease in renal blood flow diminishes the glomerular filtration rate, resulting in hypoperfusion and depletion of ATP in tubular cells $[6,34,41]$. Furthermore, the readily filtered myoglobin may precipitate (cast formation) and stop flow of urine, which may facilitate the uptake of heme proteins to tubule cells [41]. The porphyrin rings of heme are degraded by heme oxygenase (HO), a member of the cytochrome P-450 superfamily. It is the rate-limiting enzyme in heme catabolism and oxidatively degrades heme into biliverdin, iron and carbon monoxide [20]. In the kidney, the liberation of iron from cytochrome P-450 enzymes has also been demonstrated by Baliga et al. [4]. This may explain the decrease in the level of P-450 enzymes in the kidney during the first day (Figs 4 and 5). Myoglobinemia probably facilitates the uptake of heme-proteins to liver cells. It may thus induce HO that increases the concentration of P-450 enzymes in the liver microsomal fraction (Figs 6 and 7). In the kidney, the induction of HO by myoglobin has been demonstrated by Nath et al. [23]. The localization of inducible $\mathrm{HO}$ (HO-1) protein is restricted to tubule cells as a response to $\mathrm{HgCl}_{2}$ induced acute renal failure [13]. The HO-1 is considered to be a stress protein [36]. In the present study HOs may therefore paradoxically contribute to the increase in the concentration of P-450 in the liver already $24 \mathrm{~h}$ after the glycerol injection and later in the regenerating renal cells.

On the other hand, glycerol as a substrate for the enzymes CYP2E1 subfamily (a member of cytochrome P-450 superfamily) may prolong the half-life of this enzyme. Addition of glycerol to the culture medium of HEPG2 cell line has enhanced the activity, amount and half-life of CYP2E1 [40]. Glycerol in protein-bound form may inhibit degradation of CYP2E1 causing a relative increase of this enzyme in both organs.

It is of interest that DEHP caused a significant elevation in the amounts of cytochrome P-450 and $b_{5}$ in the rats injected only once with DEHP without glycerol. Such a change has not occurred when the renal failure has been induced by a surgical intervention and no significant changes were discernible during the first week. However, after two and three weeks, cytochrome P-450 significantly also increased in CRF [15]. DEPH induces proliferation of mitochondria and peroxisoma and modifies the peroxisomal enzymatic pattern (catalase, D-amino acid oxidase, palmitoyl-CoA 
oxidase, arachinoidic acid hydroxilase, etc.) in the liver, kidney and brain $[1,7,11,24$, 28, 33]. In the kidney, a DEHP-dependent CYP4A enzyme synthesis and acyl-CoA oxidase are also induced [24]. However, not all the DEHP-induced changes of peroxisomal emzyme activities are directly related to peroxisoma proliferation [28].

Two groups of patients are particularly prone to be exposed to high concentrations of plasticizers, namely those on regular hemo- and peritoneal dialysis and patients requiring repeated transfusions of whole blood and platelets $[9,30]$. DEPH exposure can be as high as $150 \mathrm{mg}$ per dialysis [9]. In experimental animals, high levels of DEPH have been found in the liver, heart, lung, kidney and fat during the first hours after administration of DEPH [26]. DEPH induces hepatocellular neoplasms in rats and mice [17], liver lesions in rhesus monkeys [16] and enhances cell replication in the kidney [38]. This compound is rapidly eliminated by kidney and liver [37] being metabolized to mono-(ethylhexyl)-phthalate (MEPH), 2-ethyl hexanoic acid and phthalic acid. In cultured kidney epithelial cells in in vitro MEPH exerts marked toxic effects. It dose-dependently decreases cell viability, alters organization of F-actin (stress fibers) and leads to lysis of cells [29]. DEPH and its metabolite MEPH may thus cause further damage in kidney especially in ARF and CRF.

ARF changes the pharmacokinetics and excretion of cyclosporine and indocianine green by liver [5, 31]. The kidney also actively metabolizes many hormones and xenobiotics [2]. Our results may indicate that hepatic and renal biotransformation of exo- and endogenous compounds may be affected by DEPH in ARF.

\section{Acknowledgements}

The financial supports of OTKA 23888, Hungary and the Medical Research Fund of Tampere University Hospital Tampere, Finland are gratefully acknowledged.

\section{REFERENCES}

1. Agrawal, D. K., Agrawal, S., Seth, P. K.: Effect of di-2-ethylhexyl phthalate on drug metabolism, lipid peroxidation and sulfhydryl content of rat liver. Drug Metab. Dispos. 10, 77-80 (1982).

2. Anders, M. V.: Metabolism of drugs by the kidney. Kidney Int. 18, 636-647 (1990).

3. Autian, J.: Toxicity and health threats of phthalate esters: review of the literature. Environ. Health Persp. 4, 3-26 (1973).

4. Baliga, R., Zhang, Z., Baliga, M., Shah, S. V.: Evidence for cytochrome P-450 as a source of catalytic iron in acute renal failure. Kidney Int. 49, 362-369 (1996).

5. Bowmer, C. J., Yates, M. S., Emmerson, J.: The effect of acute renal failure on the pharmacokinetics of indocyane green in the rat. Biochem. Pharmacol. 31, 2531-2538 (1982).

6. Börner, H., Klinkmann, H.: Pathogenesis of acute non-inflammatory renal failure. Nephron 25, 261-266 (1980). 
7. Cimini, A-M., Sulli, A., Stefanini, S., Serafini, B., Moreno, S., Rossi, L., Ceru, M. P.: Effects of di-(2ethylhexyl)-phthalate on peroxisomes of liver, kidney and brain of lactating rats and their pups. Cell Mol. Biol. 40, 1063-1076 (1994).

8. Cojocel, C., Maita, K., Pasino, D. A., Kuo, C., Hook, J. E.: Metabolic heterogeneity of proximal and distal kidney tubules. Life Sc. 33, 855-861 (1983).

9. Gibson, T. P., Briggs, W. A., Boone, B. J.: Delivery of 2-di(ethylhexyl)-phthalate to patients during hemodialysis. J. Lab. Clin. Med. 87, 519-524 (1976).

10. Guengerich, F. P.: Enzymatic oxidation of xenobiotic chemicals. Crit. Rev. Biochem. Mol. Biol. 25 , 97-153 (1990).

11. Hasihimoto, T.: Individual peroxisomal $\beta$-oxidation enzymes. Ann. N.Y. Acad. Sci. 386, 5-12 (1982).

12. Henry, R. J., Cannon, D. C., Winkelman, J. W.: Clinical Chemistry Principles and Techniques. 2nd ed., Harper and Row, London (1974).

13. Horikawa, S., Ito, K., Ikeda, S., Shibata, T., Ishizuka, S., Yano, T., Hagiwara, K., Ozasa, H., Katsuyama, I.: Induction of heme oxygenase-1 in toxic renal injury: mercuric chloride-induced acute renal failure in rat. Tox. Lett. 94, 57-64 (1998).

14. Hostetter, T. H., Wilkes, B. M., Brenner, B. M.: Renal circulatory and nephron function in experimental acute renal failure, ed. Brenner, Bm. and Lazarus, J. M. W. B. Sunders C. 1983, pp. 99-155.

15. Kertai, E., Kovács, J., Hollósi, G., Trestyánszky, Z., Varga, V.: Effect of di-2-ethylhexyl phthalate on renal cytochrome P-450 monooxygenases in surgically evoked subchronic renal failure of rats. Centr. Eur. J. Occup. Environm. Med.

16. Kevy, S. V., Jacob, M. S.: Hepatic effects of phthalate ester leached from polyvinylchloride blood bags following transfusion. Env. Health Perspect 45, 57-64 (1982).

17. Kluw, V. M., McGonnel, E. E., Huff, J. E., Haseman, J. K., Douglas, J. F., Hartwell, W. C.: Carcinogencity testing of phthalate esters and related compounds by National Toxicology Program and the National Institute. Environ Health Perspect. 45, 129-133 (1982).

18. Lohr, J. W., Willsky, G. R., Ascara, M. A.: Renal drug metabolism. Pharmacological Reviews 50, 107-141(1998).

19. Lowry, O. H., Rosebrough, N. J., Farr, A. L., Randall, R. J.: Protein measurement with the Folin phenol reagent. J. Biol. Chem. 193, 265-275 (1951).

20. Maines, M. D., Trakshel, G. M., Kutty, R. K.: Characterization of two constitutive forms of rat liver oxygenase: only one molecular species of enzyme is inducible. J. Biol. Chem. 261, 411-419 (1986).

21. Merdink, J., Decosta, K., Mathews, J. M., Jones, C. B., Okita, R. J., Okita, R. T.: Hydroxilation of lauramide diethanolamine by liver microsomes. Drug Metabol. Dispos. 24, 180-186 (1996).

22. Miles, Ph. R., Wright, J. R., Bowmann, L., Colby, H. D.: Inhibition of hepatic microsomal lipid peroxidation by drug substrates without drug metabolism. Biochem. Pharmac. 29, 565-570 (1980).

23. Nath, K. A., Balla, G., Vercolotti, G. M., Balla, J., Jacob, H. S., Levitt, M. D., Rosenberg, M. E.: Induction of heme oxygenase is a rapid and protective response in rhabdomyolysis in the rat. J.Clin. Invest. 90, 267-270 (1992).

24. Okita, J. R., Castle, P. J., Okita, R. T.: Characterization of cytochromes P-450 in liver and kidney of rats treated with di-(2-ethylhexyl)-phthalate. J. Biochem. Toxicol. 8, 135-144 (1993).

25. Okuda, S., Oh, Y., Tsuruda, H., Onoyama, K., Fujimi, S., Fujishima, M.: Adriamycin-induced nephropathy as a model of chronic progressive glomerular disease. Kidney Int. 29, 502-510 (1986).

26. Oishi, S., Hiraga, K.: Distribution and elimination of di-(ethylhexyl)-phthalate (DEPH) and mono(ethylhexyl)phthalate (MEPH) after a single oral administration of DEPH in rats. Toxicology 51, 149-155 (1982).

27. Omura, T., Sato, R.: The carbon monoxide-binding pigment of liver microsomes I. Evidence for its hemoproteins nature. J. Biol. Chem. 239, 2370-2378 (1964).

28. Reubsaet, F. A. G., Veerkamp, J. H., Dirven, H. M., Bruckwilder, M. P., Hashimoto, T., Trijbels, J. F., Monnens, L. H.: The effect of di-(2-ethylhexyl)phthalate on fatty acid oxidation and carnitine palmitoyltransferase in various rat tissues. Biochim. Biophys. Acta 1047, 264-270 (1990). 
29. Rothenbacher, K. P., Kimmel, R., Hildenbrand, S., Schmahl, F. W., Dartsh, P. C.: Nephrotoxic effecs of di-(2-ethylhexyl)-phthalate (DEPH) hydrolysis products of cultured kidney epithelial cells. Human Exp. Toxicol. 17, 336-342 (1998).

30. Rubin, R. J., Schiffer, C. A.: Fate in humans of plasticizer di-2-ethylhexyl phthalate arising from transfusions of platlets stored in vynyl plastic bags. Transfusion 16, 330-335 (1976).

31. Shibata, N., Ohmae, T., Hoshino, N., Minouchi, T., Yamaji, A.: Influence of glycerol-induced acute renal failure on the pharmacokinetics of cyclosporin. J. Pharm. Pharmacol. 51, 397-404 (1988).

32. Snedecor, G. W., Cochran, W. G.: Statistical Methods. 6th ed., p. 465. Iowa State University Press, Ames (1967).

33. Stefanini, S., Serafini, B., Nardacci, R., Vecchiioi, S. F., Moreno, S., Sartori, C.: Morphometric analysis of liver and kidney peroxisomes in lactating rats and their pups after treatment with the peroxisomal proliferator di-(2-ethylhexyl)-phthalate. Biol. Cell. (1995).

34. Stein, J. H., Lifschitz, M. D., Barnes, L. D.: Current concepts on the pathophysiology of acute renal failure. Am. J. Physiol. 234, F171 (1978).

35. Tanner, G. A.: Experimental models of acute tubular necrosis. In: Handbook of Animal Models of Renal Failure (Ash, S. R. and Thornhill, J. A. eds.) CRC Press, Boca Raton. (1985).

36. Vogt, B. A., Alam, J., Croatt, A. J., Vercellotti, G. M., Nah, K. A.: Acquired resistance to acute oxidative stress: possible role of heme oxygenase and ferritin Lab. Invest 72, 474-483 (1995).

37. Waddel, W. J., Marlowe, C., Miripol, J. E., Garvin, P. J., Martis, L.: Measurement of the renal clearence of drugs. Toxicol. Appl. Pharmacol. 45, 1-27 (1978).

38. Ward, J. M., Peters, J. M., Perella, C. M., Gonzalez, F. J.: Receptor and receptor and non receptor mediated organspecific toxicity of di-(2-ethylhexyl)-phthalate (DEPH) in peroxisome proliferatoractivated receptor alpha-null mice. Toxicol. Phathol. 26, 240-246 (1990).

39. Woodward, K. W.: Phthalate Esters: Toxicity and Metabolism Vol. II, CRC Press. Inc., Boca Raton, Florida (Effects on Humans) p. 93. (1988).

40. Yang, M. X., Cederbaum, A. I.: Glycerol increases content and activity and of human cytochrome P4502E1 in tranduced HepG2 cell line by protein stabilization. Clin. Exp. Res. 21, 340-347 (1997).

41. Zager, R. A.: Rhabdomyolysis and myoglobinuric acute renal failure. Kidney Int. 49, 314-326 (1996).

42. Zenser, T. V., Mattamal, M. B., Davis, B. B.: Differential distribution of the mixed oxidasese activities in rabit kidney. J. Pharmacol. Exp. Ther. 207, 719-725. 